J. Perinat. Med. 17 (1989) 423

\title{
Preterm premature rupture of the membranes: neonatal outcome in 215 cases of an active conservative management
}

\author{
Ingrid Theunissen and Michel van Lierde
}

Unit of Obstetrics, St. Luc University Hospital, Brussels, Belgium

\section{Introduction}

Premature rupture of the fetal membranes (PROM) leads to two main perinatal problems: prematurity and infection [3]. Prematurity occurs because usually labor begins shortly after the rupture [8]. Infection is the consequence of an open amniotic fluid cavity allowing germs to contaminate both the mother and the fetus [20]. In the literature, there is a lack of consensus about the attitude to adopt towards premature rupture of membranes [7]. The obstetrician is confronted with the choice of an optimal followup either with or without tocolysis [19, 22], antibiotic prevention [20] and hyaline membrane disease prevention by glucocorticoids [3, 4], depending on the risk for the neonate and the mother.

In the "Cliniques Universitaires $S^{t}$ Luc Brussels" an active conservative management is the option taken. After ten years of practice, we have evaluated our results by analyzing the perinatal outcome and also by comparing the premature neonates after PROM with a control group.

\section{Methodology}

Two hundred and fifteen women between 24 and 36 weeks of pregnancy with premature rupture of the membranes (PROM) were admitted in this study.

Diagnosis of PROM was based on patient's story, sterile speculum examination showing pooling amniotic fluid, and microscopic examination for "ferning". At admission, a cervical culture for group $\beta$ streptococcus was performed. An ultra-

\section{Curriculum vitae}

INGRID THEUNISSEN was born in Genk, Belgium, in 1963. She obtained her medical degree from the University of Louvain Medical School, with highest honors in 1987. She is currently doing her clinical residency in obstetrics and gynaecology. In addition, she is doing research in perinatal medecine.

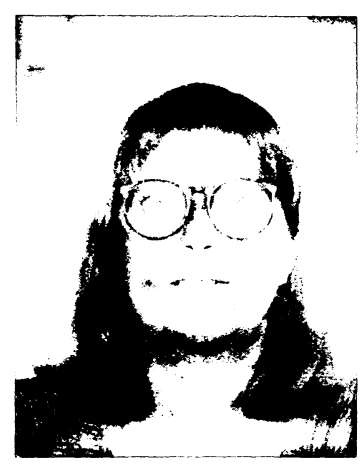

sound examination and an electronic heart rate fetal monitoring was utilized to assess fetal well being.

Criteria of exclusion were: major fetal congenital anomalies, fetal death, fetal distress, multiple pregnancies, women in labor and any obstetrical reason for immediate delivery such as vaginal bleeding or evidence of chorioamnionitis.

Treatment consisted in bed rest at the hospital, antibiotics continuously given (ampicillin $3 \times 1 \mathrm{~g}$ IVD or erythromicin $4 \times 500 \mathrm{mg}$ in case of allergy), and intravenous tocolysis by ritodrine if labor began. No vaginal desinfection was performed.

Glucocorticoids ( $\beta$-methasone $12 \mathrm{mg} /$ day IM for two days repeated once a week) were given only before 32 weeks and by the discretion of the attendant physician.

Follow-up of the patients consisted of measuring the maternal temperature, evaluating uterine 
tenderness, and performing fetal heart rate monitoring twice a day. Maternal leucocytosis and blood sedimentation speed was measured every two days. Once a week an ultrasound examination was performed to check fetal well being. A cervical/vaginal culture was also done once a week to certify a local sterilization. In case of resistance to ampicillin, the antibiotic treatment was adapted.

Pregnancy was terminated in case of suspected chorioamnionitis (based on any of the following signs: maternal fever greater than $38^{\circ} \mathrm{C}$; leucocytosis superior to 15000 ; uterine tenderness; foul smelling amniotic fluid discharge), fetal distress, labor despite tocolysis, and when gestational age reached 37 weeks. Antibiotics were given during seven days after birth to all patients. The latency period is the time between membrane rupture and birth. A latency period of less than two days is considered a failure of conservative management.

Results were evaluated by the neonatal outcome: prematurity, birth weight, Apgar score at 1 and $5 \mathrm{~min}$, incidence of neonatal hyaline membrane disease (HMD), neonatal infection, and early neonatal death (first week of life). Diagnosis of hyaline membrane disease was based on clinical evaluation and on characteristic lung radiography; wet lung, transcient respiratory distress, and post-anoxic distress were diagnosed seperate from HMD.

Neonatal infection consisted of a positive central culture such as blood, cephalo-rachidian fluid or urine, or a clinical evaluation showing evidence of infection (leucocytosis, response to antibiotics, ...).

Neonatal outcome was compared to neonatal outcome of babies born prematurely for another etiological reason; each premature neonate following PROM was matched with a premature neonate of the same birth age and year of birth in order to compare similar neonatal management. The benefit of pregnancy prolongation after PROM and the group of neonates born at 37 weeks of gestation (not premature) were not considered when compared to the control group.

Statistical analysis consisted of Chi-square tests of independence performed on groups separated by the procedure CROSSTAB of the statistical package SPSS [26].

\section{Results}

From 1978 to 1987, 215 women with single pregnancies and PROM entered this retrospective study. Gestational age ranged from 26 weeks to 36 weeks of amenorrhea, 113 PROM cases occured before 35 weeks.

Reasons for termination of pregnancy and the overall neonatal results are listed (table I). In our series we had no congenital malformation and no prenatal death.

Pregnancy age at membrane rupture is a major factor in determining the outcome (table II). The latency period decreases with advanced gestational age. Suspicion of chorioamnionitis is significantly more frequent at low gestational age. The overall neonatal outcome is highly significantly $(\mathrm{P}<0.01)$ related to gestational age. In the group of PROM occuring at 35 and 36 weeks of gestation, there is no neonatal death, no HMD, and only one case (1\%) of neonatal infection.

Glucocorticoid treatment in PROM occuring before 33 weeks of pregnancy was administrated in 28 cases out of $58(48.3 \%)$. No difference in neonatal outcome are found respectively with and without treatment: rates of hyaline membrane disease $(17.9 \%$ vs $20.0 \%)$, of neonatal infection $(21.4 \%$ vs $26.7 \%)$ and of neonatal death $(10.7 \%$ vs $3.3 \%)$ are similar. The rate of suspected chorioamnionitis is also similar in the two groups (35.7\% vs $36.7 \%)$.

When pregnancy is terminated because of the suspicion of chorioamnionitis, the neonatal outcome is compromised; the incidence of neonatal infection is significantly $(P<0.001)$ related to the suspicion of chorioamnionitis (table III). Seventy cases $(32.6 \%)$ of PROM had a prolonged latency period ( $\geq 7$ days). When comparing the pregnancy outcome with PROM having a shorter latency period, we found no difference. Especially, the incidence of chorioamnionitis $(14.5 \%$ vs $24.3 \%$, respectively in the short and prolonged latency groups) and of neonatal infection $(6.9 \%$ vs $12.9 \%)$ are not statistically different.

When pregnancy termination was motivated by a gestational age of 37 weeks, $(\mathrm{N}=46,21.4 \%)$ fetal grwoth seems to be slowed down. Indeed, the incidence of birth weight inferior to the tenth percentile was significantly $(P<0.001)$ more frequent in the group reaching 37 weeks of gestation 
Table I. Premature rupture of the membranes: Conservative management, overall results

\begin{tabular}{|c|c|c|c|c|}
\hline & \multicolumn{2}{|c|}{ PROM } & \multicolumn{2}{|c|}{ PROM } \\
\hline & \multicolumn{2}{|c|}{$\begin{array}{l}\text { before } 35 \text { weeks } \\
113 \text { cases }\end{array}$} & \multicolumn{2}{|c|}{$\begin{array}{l}\text { before } 37 \text { weeks } \\
215 \text { cases }\end{array}$} \\
\hline \multicolumn{5}{|l|}{ Termination of pregnancy: } \\
\hline - suspicion of chorioamnionitis & 31 & $27.4 \%$ & 38 & $17.7 \%$ \\
\hline - 37 weeks reached & 7 & $6.2 \%$ & 46 & $21.4 \%$ \\
\hline - failure of tocolysis & 62 & $54.9 \%$ & 113 & $52.6 \%$ \\
\hline - pathologic fetal heart rate & 10 & $8.8 \%$ & 13 & $6.0 \%$ \\
\hline - others & 3 & $2.7 \%$ & 5 & $2.3 \%$ \\
\hline \multicolumn{5}{|l|}{ Neonatal results: } \\
\hline \multicolumn{5}{|l|}{ - prematurity: } \\
\hline * before 37 weeks & 106 & $93.8 \%$ & 169 & $78.6 \%$ \\
\hline * before 35 weeks & 85 & $75.2 \%$ & 85 & $39.5 \%$ \\
\hline * before 33 weeks & 51 & $45.1 \%$ & 51 & $23.7 \%$ \\
\hline \multicolumn{5}{|l|}{ - birth weight: } \\
\hline$*<1000 \mathrm{~g}$ & 8 & $7.1 \%$ & 8 & $3.7 \%$ \\
\hline$*<1500 \mathrm{~g}$ & 26 & $23.0 \%$ & 26 & $12.1 \%$ \\
\hline$*<2000 \mathrm{~g}$ & 58 & $51.3 \%$ & 60 & $27.9 \%$ \\
\hline$*<2500 \mathrm{~g}$ & 85 & $75.2 \%$ & 111 & $51.6 \%$ \\
\hline \multicolumn{5}{|l|}{ - Apgar scores <7: } \\
\hline * at $1 \mathrm{~min}$ & 71 & $62.8 \%$ & 99 & $46.0 \%$ \\
\hline * at $5 \mathrm{~min}$ & 31 & $27.4 \%$ & 34 & $15.8 \%$ \\
\hline - Hyaline membrane disease & 15 & $13.3 \%$ & 15 & $7.0 \%$ \\
\hline - Neonatal infection & 18 & $15.9 \%$ & 19 & $8.8 \%$ \\
\hline - Neonatal death & 4 & $2.5 \%$ & 4 & $1.9 \%$ \\
\hline
\end{tabular}

$(\mathrm{N}=9,19.6 \%$; versus $\mathrm{N}=4,2.4 \%$ in the group not reaching 37 weeks).

When PROM led to premature birth, the premature neonates before 33 weeks of gestation did not differ from the control premature neonates (table IV). When birth happened before 35 weeks and before 37 weeks, there is a lower incidence of HMD and neonatal death in premature neonates following PROM compared to the control group.

\section{Discussion}

The first problem relating to PROM seems to be infection, maternal and/or neonatal. The studies of JoHnSON [18], MiLLER [20] and BLACKMON [3] show that the later the PROM occurs during the pregnancy, the smaller is the overall risk of infection. This is in agreement with our results. However, according to others, pregnancy age modifies the risk of chorioamnionitis but not the neonatal sepsis [1].
The controversy about the benefit versus the risk of delaying labor after PROM is the main problem concerning the management of PROM. According to the literature, the risk of chorioamnionitis is variously related to the latency period: many authors find no relationship $[6,14,18,20$, $28,36,38]$ while others find a negative relationship $[1,9,12,16,33,34]$.

Similar controversial results are found about the incidence of neonatal infection, but the actual conclusion seems to be that there is no relationship between the length of the latency period and the neonatal infection $[1,3,9,16,28,30]$. We find that a prolonged latency period ( $\geq 7$ days) does not increase the risk of chorioamnionitis nor the risk of neonatal infection.

The benefit of conservative management lies in the reduction of HMD, a major complication of prematurity. A recent report [3] shows the positive effect of a prolonged latency even if previous studies tend to find no relationship $[1,9,11,19$, $23,34]$. Our results however, also show a trend 


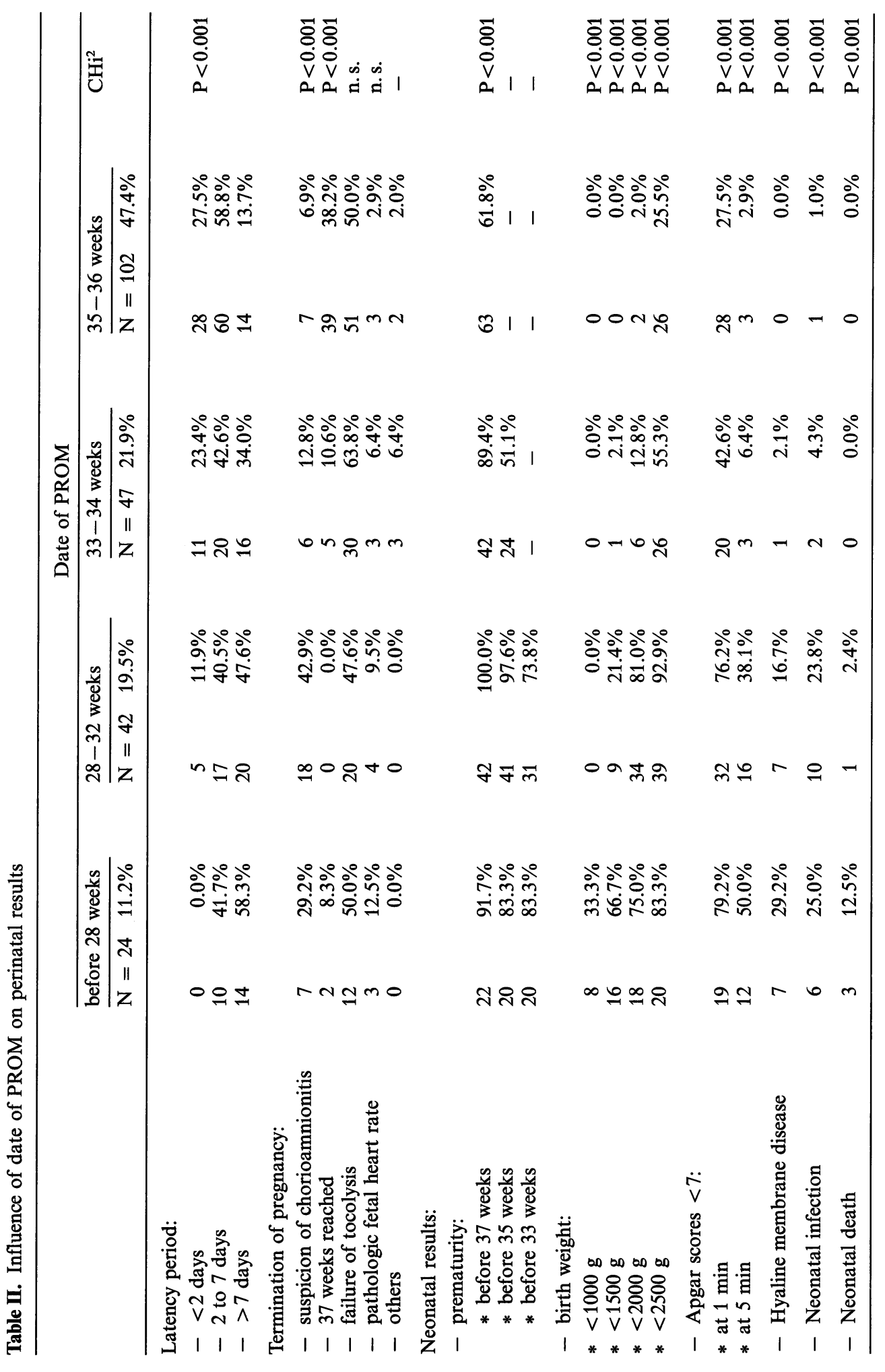


Table III. Effect of chorioamnionitis on neonatal outcome

\begin{tabular}{|c|c|c|c|c|c|}
\hline & \multicolumn{2}{|c|}{ Chorioamnionitis } & \multicolumn{2}{|c|}{ No chorioamnionitis } & \multirow[t]{2}{*}{$\mathrm{CHi}^{2}$} \\
\hline & $\mathrm{N}=38$ & $7.7 \%$ & $\mathrm{~N}=177$ & $82.3 \%$ & \\
\hline \multicolumn{6}{|l|}{ Prematurity: } \\
\hline * before 37 weeks & 38 & $100.0 \%$ & 131 & $74.0 \%$ & $\mathrm{P}<0.001$ \\
\hline$*$ before 35 weeks & 27 & $71.1 \%$ & 58 & $32.8 \%$ & $P<0.001$ \\
\hline$*$ before 33 weeks & 17 & $44.7 \%$ & 34 & $19.2 \%$ & $\mathrm{P}<0.001$ \\
\hline \multicolumn{6}{|l|}{ Birth weight: } \\
\hline$*<1000 \mathrm{~g}$ & 4 & $10.5 \%$ & 4 & $2.3 \%$ & $\mathrm{P}<0.05$ \\
\hline$*<1500 \mathrm{~g}$ & 9 & $23.7 \%$ & 17 & $9.6 \%$ & $\mathrm{P}<0.05$ \\
\hline$*<2000 \mathrm{~g}$ & 21 & $55.3 \%$ & 39 & $22.0 \%$ & $\mathrm{P}<0.001$ \\
\hline$*<2500 \mathrm{~g}$ & 27 & $71.1 \%$ & 84 & $47.5 \%$ & $\mathrm{P}<0.01$ \\
\hline \multicolumn{6}{|l|}{ Apgar scores $<7$ : } \\
\hline * at $1 \mathrm{~min}$ & 26 & $68.4 \%$ & 73 & $41.2 \%$ & $\mathrm{P}<0.01$ \\
\hline * at $5 \mathrm{~min}$ & 13 & $34.2 \%$ & 21 & $11.9 \%$ & $\mathrm{P}<0.001$ \\
\hline Hyaline membrane disease & 3 & $7.9 \%$ & 12 & $6.8 \%$ & n.s. \\
\hline Neonatal infection & 9 & $23.7 \%$ & 10 & $5.6 \%$ & $\mathrm{P}<0.001$ \\
\hline Neontal death & 0 & $0.0 \%$ & 4 & $2.2 \%$ & n.s. \\
\hline
\end{tabular}

of decreasing incidence of HMD with prolonged latency, but it is not statistically significant ( $\mathrm{P}=0.079$ for PROM before 35 weeks).

In order to accelerate lung maturation, the administration of $\beta$-methasone is recommended [29]. The majority of reported studies find no difference in the incidence of HMD when corticosteroids were given $[3,4,13,19,38]$. Our results are in agreement with these studies. But, according to SPINNATo [32] these results are not to be considered because the treatment is applied to a low risk population and needs, for further evaluation, to be applied where the potential benefit of lung maturation really exists. Corticoids are known to be related to an increased risk of infection, and in a situation such as PROM where infection is threatening it may be dangerous to use them. For some authors glucocorticoid administration increases the maternal infection risk but not the neonatal infection risk [1], while for other authors it increases the neonatal but not the maternal infection risk [31]. Other authors find that glucocorticoid administration does not increase any infection risk [38], and finally, there are authors who find an increased maternal and neonatal infection risk [3, 24]. We do not find any increased incidence of chorioamnionitis nor neonatal infection when patients received $\beta$-methasone. Since we observe no benefit in glucocorticoids administration and there is doubt about the infection risk, we recommend to not use them.

When chorioamnionitis is clinically suspected, pregnancy should be stopped. The increased risk of neonatal infection associated with chorioamnionitis seems generaly accepted $[2,3,20]$ but the relation with neonatal death is still controversial $[16,34,40]$. Our results show that clinical suspicion of chorioamnionitis is related with a higher incidence of neonatal infection but not with higher neonatal death rate.

Hypoplastic lungs after prolonged PROM is well described [26, 37]. For some authors, PROM does not affect the growth process $[3,18]$ but for others, PROM slows the growth $[5,35]$. In our study we have no prenatal death, no congenital malformation, but fetuses seem to be slower in their growth. Our control group compares the premature neonate after PROM with a control premature neonate. The results show less HMD and a lower rate of neonatal death after PROM. The principle that PROM decreases the risk of HMD [3, 9] and the results of BLACKMON [3] who finds a decreased perinatal mortality are in agreement with our results. MOBERG [21] finds an increased incidence of neonatal infection fol- 


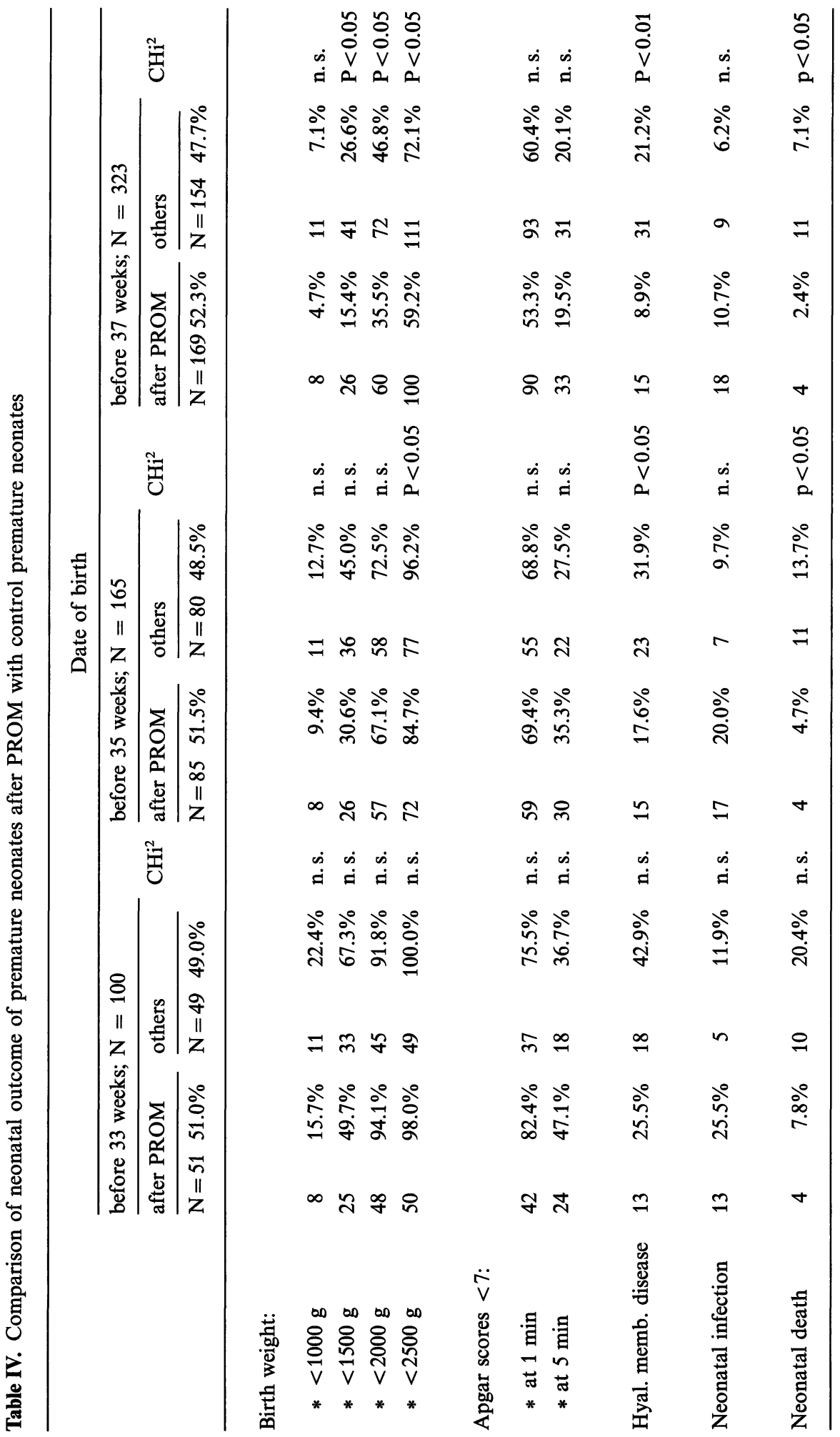


Table V. Overall neonatal outcome compared with the literature data

\begin{tabular}{|c|c|c|c|c|c|}
\hline & \multicolumn{2}{|c|}{ Our results } & \multicolumn{2}{|c|}{ Literature data } & \multirow[b]{2}{*}{ Ref } \\
\hline & Incidence & Date of PROM & Incidence & Date of PROM & \\
\hline HMD & $\begin{array}{r}7 \% \\
13 \%\end{array}$ & $\begin{array}{l}\text { before } 37 \text { weeks } \\
\text { before } 35 \text { weeks }\end{array}$ & $\begin{array}{l}14 \% \\
12.8 \% \\
80 \%\end{array}$ & $\begin{array}{l}26-36 \text { weeks } \\
26-36 \text { weeks } \\
\text { before } 32 \text { weeks }\end{array}$ & $\begin{array}{l}{[10]} \\
{[38]} \\
{[19]}\end{array}$ \\
\hline $\begin{array}{l}\text { Neonatal } \\
\text { infection }\end{array}$ & $\begin{array}{r}9 \% \\
16 \%\end{array}$ & $\begin{array}{l}\text { before } 37 \text { weeks } \\
\text { before } 35 \text { weeks }\end{array}$ & $\begin{array}{l}8.5 \% \\
30.1 \% \\
14 \% \\
21 \%\end{array}$ & & $\begin{array}{l}{[38]} \\
{[39]} \\
{[29]} \\
{[10]}\end{array}$ \\
\hline $\begin{array}{c}\text { Neonatal } \\
\text { death }\end{array}$ & $\begin{array}{l}2 \% \\
3 \%\end{array}$ & $\begin{array}{l}\text { before } 37 \text { weeks } \\
\text { before } 35 \text { weeks }\end{array}$ & $\begin{array}{c}3.3 \% \\
4.5 \% \\
15 \% \\
3.1 \% \\
16 \%\end{array}$ & $\begin{array}{l}\text { before } 37 \text { weeks } \\
28-35 \text { weeks } \\
26-34 \text { weeks } \\
26-36 \text { weeks } \\
26-32 \text { weeks }\end{array}$ & $\begin{array}{l}{[1]} \\
{[21]} \\
{[16]} \\
{[16]} \\
{[29]}\end{array}$ \\
\hline
\end{tabular}

lowing PROM, which contradicts the findings of CURET [9]. When we compare premature neonates after PROM to the control premature neonates, there is no difference in the infection risk.

Our management of PROM which consists of an active and conservative management differs from the actual approach recommended by the literature $[1,4,8,12,16,19,22,24,28]$. Nevertheless, we think that our management is justifiable. PROM occuring before 28 weeks of gestation generally leads to fetal loss. However, our management led to a neonatal mortality rate of only $12 \%$ with a rate of $29 \%$ for HMD, $25 \%$ of neonatal infection and $33 \%$ of birth weight under $1000 \mathrm{~g}$. We had no latency period of less than two days. Moreover, when PROM occured after 34 weeks of pregnancy, our conservative management avoided prematurity in $38 \%$ of the neonates with no neonatal death and no HMD. Only one case $(1 \%)$ of neonatal infection was the resulting risk.

When compared with the literature, our rate of chorioamnionitis seems rather high: $18 \%$ before 37 weeks versus $12 \%$ [11], 5.2\% [38], 5.3\% [6] and $27 \%$ before 35 weeks versus $16 \%$ [15], $27 \%$ [27], $18 \%$ [17], 25\% [16]. However, when comparing the neonatal outcome, which is the most important criteria, our PROM management is substantially more encouraging than the traditional management (table V).

\begin{abstract}
The aim of the study is to evaluate an active conservative management (tocolysis and antibiotics administration) in preterm premature rupture of the membranes (PROM), applied to 215 singleton pregnancies. Pregnancies are continuated until 37 weeks of gestation if the clinical and biological follow-up shows no risk for the mother and the fetus. The neonatal results were analysed by statistical methods and were compared to the outcome of a control group of premature neonates. Our results show that the outcome is mostly determined by gestational age at membrane rupture. No
\end{abstract}

benefit nor risk was added when glucocorticoids were administrated. Clinical suspicion of chorioamnionitis increases the risk of neonatal infection. A prolonged latency period ( $\geq 7$ days) does not increase the maternal or fetal infection risk. When birth happened before 35 weeks and before 37 weeks, the premature neonate after PROM has a lower incidence of hyaline membrane disease and neonatal death compared with the control group. These results are in favor of an active conservative management in PROM.

Keywords: Chorioamnionitis, glucocorticoid, hyaline membrane disease, latency period, neonatal death, neonatal infection, premature rupture of fetal membranes. 


\section{Zusammenfassung}

Neonatales Outcome in 215 Fällen bei vorzeitigem Blasensprung und aktivem „,klassischen“ Management

Der vorzeitige Blasensprung bei Geburtsunreife ist ein Hauptproblem der Geburtshilfe. In unserer Abteilung führen wir eine Antibiose sowie eine Tokolyse mit Ritodrin durch. Wenn aus geburtshilflicher Sicht Glukokortikoide gerechtfertigt erscheinen, werden diese zur Akzeleration der Lungenreifung eingesetzt. Wir würden dieses Vorgehen als aktives konservatives bzw. klassisches Management bezeichnen. Der klinische Verlauf sowie die Kontrolle der Laborparameter erlauben die Fortsetzung der Schwangerschaft ohne Risiko, welches meist durch eine Infektion droht, für Mutter und Fet. Mit Erreichen der 37. Woche wurden die Schwangerschaften beendet. Über einen Zeitraum von 10 Jahren wurde dieses Vorgehen bei 215 Einlingsschwangerschaften mit vorzeitigem Blasensprung und Geburtsunreife angewandt. Das neonatale Outcome wurde statistisch analysiert. Darüberhinaus haben wir dieses Kollektiv verglichen mit einer Kontrollgruppe von Frühgeborenen ohne vorzeitigen Blasensprung.
Die Ergebnisse zeigen, das das Outcome in erster Linie durch das Gestationsalter zum Zeitpujkt des Blasensprung bedingt ist (Tabelle II). Die Gabe von Glukokortikoiden brachte keine Vorteile, erhöhte aber auch nicht das Risiko. Bei klinischem Verdacht auf eine Chorioamnionitis wurde häufiger eine neonatale Infektion bestätigt (Tabelle III). Eine längere Latenzzeit ( $\geq 7$ Tage) erhöhte nicht das Risiko einer maternalen oder fetalen Infektion. Bei Geburt vor der 35. bzw. vor der 37. Woche hatten Frühgeborene nach vorzeitigem Blasensprung seltener ein Atemnotsyndrom als Kinder der Kontrollgruppe. Auch die neonatale Sterblichkeit war geringer (Tabelle IV).

Diese Ergebnisse haben ihren Stellenwert in den zahlreichen und kontroversen Arbeiten zum vorzeitigen Blasensprung. Unser aktives „klassisches“ Management stimmt nicht mit der heutigen Vorgehensweise beim vorzeitigen Blasensprung überein. Dennoch sind unsere Ergebnisse hinsichtlich des neonatalen Outcome im Literaturvergleich ermutigend (Tabelle V).

Schlüsselwörter: Atemnotsyndrom, Chorioamnionitis, Glukokortikoide, Latenzzeit, neonatale Infektion, neonatale Sterblichkeit, vorzeitiger Blasensprung.

\section{Résumé}

Rupture prématurée des membranes ovulaires: résultat néonatal dans 215 cas d'un traitement conservateur actif La rupture prématurée des membranes ovulaires (RPM) est un problème obstétrical majeur qui bénéficie dans notre institution d'un traitement conservateur actif. Le traitement consiste en une antibiothérapie et en une tocolyse à base de ritodrine ainsi que l'administration de glucocorticoïdes dans le but d'accélérer la maturation pulmonaire, si l'état obstétrical en indique l'utilité. Une surveillance clinique et biologique permet de prolonger la grossesse sans risques (principalement infectieux) pour la mère et le fetus. Une fois le terme de 37 semaines atteint, la grossesse est interrompue. Sur une période de 10 ans ce traitement a été appliqué à 215 grossesses monofotales avec RPM. Les résultats périnataux ont été évalués par analyse statistique. Nous avons également comparé le devenir néonatal des nouveaux-nés prématurés après RPM à un groupe contrôle de prématurés.
Le résultat néonatal semble principalement déterminé par l'âge gestationnel au moment de la rupture (tableau II). Aucun bénéfice ni risque n'ont été mis en évidence suite à l'administration de glucocorticoïdes. La suspicion clinique de chorioamniotite augmente le risque d'infection néonatale (tableau III). Une période de latence prolongée ( $\geq 7$ jours) n'augmente pas le risque infectieux maternel ou néonatal. Quand la naissance survient avant 35 semaines et avant 37 semaines, la prématurité après RPM présente un taux de maladie des membranes hyalines et de mortalité néonatale plus bas que celui du groupe contrôle (tableau IV).

Ces résultats s'inscrivent dans l'abondante et contradictoire littérature concernant la RPM. Notre traitement conservateur actif ne correspond pas à l'approche actuelle de la RPM, mais nos résultats néonataux comparés à ceux de la littérature sont encourageants (tableau V).

Mots-clés: Choriamniotite, déces néonatal, glucocorticoïdes, infection néonatale, maladie des membranes hyalines, période de latence, rupture prématurée des membranes ovulaires.

\section{References}

[1] ANDReyko JL, CP Chen, AT Shennan, JE MilLIGAN: Results of conservative management of premature rupture of the membranes. Am J Obstet Gynecol 148 (1984) 600
[2] Aubriot FX, MC Lafay, R Taurelle: La rupture prématurée des membranes. A propos de 169 observations relevées à la maternité de l'hôpital Boucicaut. J Gyn obst Biol Repr 12 (1983) 423 
[3] Blackmon LR, LS Alger, C Crenshaw, JR: Fetal and neonatal outcomes associated with premature rupture of the membranes. Clin Obstet Gynecol 29 (1986) 779

[4] BLANCO JD: Rupture of the membranes in preterm gestation. Clin Obstet Gynecol 27 (1984) 60

[5] BotToms SF, RA Welch, IE ZADOR, RJ SoKol: Clinical interpretation of ultrasound measurements in preterm pregnancies with premature rupture of the membranes. Obstet Gynecol 69 (1987) 358

[6] Broekhuizen FF, M Gilman, PR Hamilton: Amniocentesis for gram stain and culture in preterm premature rupture of the membranes. Obstet Gynecol 66 (1985) 316

[7] CAPEless EL, PB MEAD: Management of preterm premature rupture of membranes: Lack of a national consensus. Am J Obstet Gynecol 157 (1987) 11

[8] Cox, SM, ML Williams, KJ Leveno: The natural history of preterm ruptured membranes: What to expect of expectant management. Obstet Gynecol 71 (1988) 558

[9] Curet LB, AV RaO, RD ZaChMaN, JC MorriSON, G Burkett, WK POOLE, C BAUER: Association between ruptured membranes, tocolytic therapy, and respiratory distress syndrome. Am J Obstet Gynecol 148 (1984) 263

[10] Douvas SG, MJ BREWER, ML Mc KaY, PG RHODES, JH KaHLSTORF, JC MORRISON: Treatment of premature rupture of the membranes. $J$ Reprod Med 29 (1984) 741

[11] DRUZIN ML, M TOTH, WJ LeDGer: Nonintervention in premature rupture of the amniotic membranes. Surg Gynecol Obstet 163 (1986) 5

[12] FERRELL RE: Management of preterm premature rupture of membranes. J Florida MA 70 (1983) 739

[13] GARITE TJ: Premature rupture of the membranes: The enigma of the obstetrician. Am J Obstet Gynecol 151 (1985) 1001

[14] GonIK B, SF Bottoms, DB Cotron: Amniotic fluid volume as a risk factor in preterm premature rupture of the membranes. Obstet Gynecol 65 (1985) 456

[15] Hawrylyshyn P, P Bernstein, JE Milligan, S. Soldin, A Pollard, B ChIR, FR Papsin: Premature rupture of membranes: The role of $\mathrm{C}$ reactive protein in the prediction of chorioamniotitis. Am J Obstet Gynecol 147 (1983) 240

[16] Hurwitz A, A Adoni, Z Palti, A Milwidsky: Is conservatives management of preterm rupture of membranes justified? Int J Gynaecol Obstet 22 (1984) 131

[17] Ismail MA, MJ Zinaman, RI LowensoHn, AH MOAWAD: The significance of $\mathrm{C}$-reactive protein levels in women with premature rupture of membranes. Am J Obstet Gynecol 151 (1985) 541

[18] JoHNSON JW, NH DAIKOKU: Prepartal rupture of the chorioamnion. Birth Defects 21 (1985) 73
[19] Kossmann JC, G Mellier, B L Salle: Conséquences des ruptures prématurées des membranes à 32 semaines de gestation et moins sur la morbidité et la mortalité néonatales. Ann Pediat 31 (1984) 361

[20] Miller JM; JG PastoreK II: The microbiology of premature rupture of the membranes. Clin Obstet Gynecol 29 (1986) 739

[21] MOBERG LJ, TJ GARITE, RK FREEMAN: Fetal heart rate patterns and fetal distress in pateints with preterm premature rupture of membranes. Obstet Gynecol 64 (1984) 60

[22] Monif GR, R Hume JR, RC Goodlin: Neonatal considerations in the management of premature rupture of the fetal membranes. Obstet Gynecol Survey 41 (1986) 531

[23] Morales WJ, MD Diebel, AJ Lazar, D ZaDROZNY: The effect of antenatal dexamethasone administration on the prevention of respiratory distress syndrome in preterm gestations with premature rupture of membranes. Am J Obstet Gynecol 154 (1986) 591

[24] Nelson LH, PJ Meis, CG Hatjis, JM Ernest, R DILlARD, HM SCHEY: Premature rupture of membranes: A prospective, randomized evaluation of steroids, latent phase, and expectant management. Obstet Gynecol 66 (1985) 55

[25] Nie NH, CH Hull, JG Jenkins, K SteinbrenNERER, DH BENT: Statistical Package for the Social Sciences. McGraw-Hill, New York 1975

[26] Nimrod C, F VArela-GitTings, G Machin, D Campbell D, $R$ Wesenberg: The effect of very prolonged membrane rupture on fetal development. Am J Gynecol 148 (1984) 540

[27] Romen Y, J Greenspoon, R ARtal: Clinical chorioamniotitis-analysis of the incubation period in patients with premature rupture of membranes. Am J Perinat 2 (1985) 314

[28] RuDD EG: Premature rupture of the membranes: A review. J Reprod Med 30 (1985) 841

[29] SCHMidt PL, ME Sims, HT Strassner, RH PAul, E Mueller, D Mc CART: Effect of antepartum glucocorticoid administration upon neonatal respiratory distress syndrome and perinatal infection. Am J Obstet Gynecol 148 (1984) 178

[30] Shaver DC, JA Spinnato, D WhybreW, WK Williams, GD ANDERSON: Comparison of phospholipids in vaginal and amniocentesis specimens of patients with premature rupture of membranes. Am J Obstet Gynecol 156 (1987) 454

[31] Simpson GF, GM HARBERT: Use of $\beta$-Methasone in management of preterm gestation with premature rupture of membranes. Obstet Gynecol 66 (1985) 168

[32] SPINNATo JA: Infrequency of pulmonary immaturity in an indigent population with premature rupture of the membranes. Obstet Gynecol 69 (1987) 942

[33] Spinnato JA, DC Shaver, EM Bray, J Lipshitz: Preterm premature rupture of the membranes 
with fetal pulmonary maturity present: A prospective study. Obstet Gynecol 69 (1987) 196

[34] Spitzer M, A Fleischer, H Schulman, G FarMAKIDES: Impact of perinatal asphyxia, mode of delivery, and duration of premature rupture of membranes on the incidence of the respiratory distress syndrome. NY State J Med 86 (1986) 64

[35] TAMURa RK, RE SabBagha, R DePp, N VaisRub, SL DoOley, ML Socol: Diminished growth in fetuses born preterm after spontaneous labor or rupture of membranes. Am J Obstet Gynecol 148 (1984) 1105

[36] TAYLOR J, TJ GARITE: Premature rupture of membranes before fetal viability. Obstet Gynecol 64 (1984) 615

[37] Van Dongen PW, J Antonissen, HW Jongsma, JM SPORKEN, PR HEIN: Lethal lung hypoplasia in infants after prolonged rupture of membranes. Eur J Obstet Gynecol Reprod Biol 25 (1987) 287

[38] VAn Dorsten JP, EO Horger, MC Miller: Preterm rupture of the membranes: Combination therapy. Am J Obstet Gynecol 153 (1985) 147
[39] Vintzileos AM, WA Campbell, D Nochimson, ME CONNOLLY, MM Fuenfer, GJ HoEHN: The fetal biophysical profile in patients with premature rupture of the membranes: An early predictor of fetal infection. Am J Obstet Gynecol 152 (1985) 510

[40] Vintzileos AM, WA Campbell, D Nochimson, PJ WeINBAuM: Fetal breathing as a predictor of infection in premature rupture of the membranes. Obstet Gynecol 67 (1986) 813

Received July 1, 1989. Accepted August 31, 1989.

Michel van Lierde

Unité d'Obstétrique

Cliniques Universitaires $S^{t}$ Luc

Av. Hippocrate 10

B-1200 Brussels

Belgium 